\title{
To Boldly Go Where No Court Has Gone Before. The German Federal Constitutional Court's ultra vires Decision of May 5, 2020
}

\author{
Franz C. Mayer*
}

(Received 05 July 2020; accepted 07 July 2020)

Keywords: PSPP; German Constitutional Court; ECB; EU law; ECJ

\section{European Constitutional Law. The final frontier.}

These are the voyages of the Second Senate of the German Federal Constitutional Court. Its mission: to explore strange new worlds. To seek out new concepts of defending national constitutionalism.

To boldly go where no national court has gone before... ${ }^{1}$

I like using popular culture references to make a point or to illustrate a law-in-context aspect that is difficult to capture. ${ }^{2}$ The Second Senate as some kind of space ship, en route to fight the Klingons of the European Court of Justice ... there is also some comic relief here, if one engages in a reflection on who is the Captain Kirk of German Constitutional Law.

But unfortunately, the present matter is too serious to push this reference too far. What happened on May 5, 2020 is not funny at all.

\section{A. The Facts}

On May 5, 2020, the Second Senate of the Federal Constitutional Court delivered its final judgment on the constitutional complaints raised against the European Central

\footnotetext{
${ }^{\star}$ Prof. Dr. jur., LL.M. (Yale), University of Bielefeld, Faculty of Law. This article builds on the German language contribution Franz C. Mayer, Auf dem Weg zum Richterfaustrecht?, VerfassungsBloG (May 7, 2020), https://verfassungsblog.de/ auf-dem-weg-zum-richterfaustrecht/. I wish to thank Moritz Kleist, Odey Hardan (both Bielefeld) and Simon Thies (Cambridge/Bielefeld) for their invaluable assistance in finalising this article.

${ }^{1}$ The origin and the evolution of this famous opening sentence of the Star Trek TV series is explained in detail in https:/en. wikipedia.org/wiki/Where_no_man_has_gone_before.

${ }^{2}$ Franz C. Mayer, Rashomon in Karlsruhe: A reflection on democracy and identity in the European Union: The German Constitutional Court's Lisbon decision and the changing landscape of European constitutionalism, 9 INT'L J. CONST. L. 757 (2011); Franz C. Mayer, Rebels without a Cause? A Critical Analysis of the German Constitutional Court's OMT Reference, 15 German L.J. 111 (2014); Franz C. Mayer and Christian Heidfeld, Episode I-Eurobonds: The Phantom Menace, Verfassungsblog (June 5, 2012), http://verfassungsblog.de/eurobonds-episode-ii-bail-member-states/ to Episode VI -The Return of the Jedi: Projektbonds, VerfassungsbloG (June 5, 2012), http://verfassungsblog.de/eurobonds-episodevi-return-jedi-projektbonds/.
}

(C) The Author(s), 2020. Published by Cambridge University Press on behalf of the German Law Journal. This is an Open Access article, distributed under the terms of the Creative Commons Attribution licence (http://creativecommons.org/licenses/by/4.0/), which permits unrestricted re-use, distribution, and reproduction in any medium, provided the original work is properly cited. 
Bank's bond purchase program 'PSPP'. ${ }^{3}$ The constitutional complaints had been pending since 2015.

The Court found the ECB's PSPP to be unconstitutional. Actually, it found the PSPP to be not in compliance with the German constitution because it considered it to be not in compliance with European Union law, as it has no basis in EU competences. Wait, no, that still doesn't reflect it properly. Let me try again.

In the dispositive part of the judgment, the Tenor, ${ }^{4}$ it says that the German Federal Government and the German Bundestag (the German parliament) violated the German constitution (the principle of democracy) by omitting to take appropriate measures against the ECB not checking and explaining that the PSPP is in compliance with EU law (the principle of proportionality). On all other counts, the constitutional complaints were unsuccessful.

In case you are already confused-it gets even better: the European Court of Justice had already confirmed the PSPP's compatibility with European Union law in a 2018 ruling in the Weiss-case, ${ }^{5}$ answering a preliminary question from - the German Federal Constitutional Court.

The Federal Constitutional Court's main point of critique is the lack of an EU law proportionality assessment with regard to the ECB's PSPP. ${ }^{6}$ Before assessing this ECB action themselves, the German court first had to get the contrary CJEU judgment out of the way.

To understand how that could be possible and in order to understand what this is all about, one has to take a step back.

\section{B. History}

According to Art. 19 TEU and Art. 267(3) TFEU, the Court of Justice of the European Union is the court of last resort for questions of interpretation and validity of European Union law. Who else? In Art. 344 TFEU, the Member States even promised each other the following: "Member States undertake not to submit a dispute concerning the interpretation or application of the Treaties to any method of settlement other than those provided for therein".

And the designated court for EU law, that simply is the CJEU.

Nevertheless, since the Maastricht judgment of $1993,{ }^{7}$ the Federal Constitutional Court has claimed for itself to be in a position to determine transgression of competences of EU institutions and organs and to declare the corresponding legal acts inapplicable for Germany. Initially, this was referred to as ausbrechende Rechtsakte, ${ }^{8}$ literally 'acts breaking out', later the Court switched to "ultra vires acts".

Since the Maastricht ruling, the Court actually uses a trick: It argues that it is just interpreting German constitutional law, the reach of the powers transferred and transferrable to the EU under the German constitution. But this constitutes a legal backdoor, the Court gets to interpret EU law itself through — a task which is reserved to the CJEU in its final sense-and in doing so, it creates a kind of parallel version of EU law, a Karlsruhe version, so to speak.

Ultimately, this approach is bound to cause conflict. It was never in accordance with the treaties anyway, considering Art. 344 TFEU (see supra). Ironically, it's the Federal Constitutional Court's ultra vires approach that turns out to be ultra vires itself.

\footnotetext{
${ }^{3}$ Bundesverfassungsgericht [BVerfG] [Federal Constitutional Court], Case No. 2 BvR 859/15 (May 5, 2020), http://www. bverfg.de/e/rs20200505_2bvr085915en.html [hereinafter Judgement of May 05, 2020].

${ }^{4}$ Judgement of May 05, 2020 at "Judgement."

${ }^{5}$ ECJ, Case C-493/17, Weiss and Others, ECLI:EU:C:2018:1000, Judgement of Dec. 11, 2018.

${ }^{6} J$ udgement of May 05, 2020 at para 167-176.

${ }^{7}$ Bundesverfassungsgericht [BVerfG] [Federal Constitutional Court] Oct. 12, 1993, 89 ENTSCHEIDUNGEN DES BUNDESVERFASSUNGSGERICHTS [BVERFGE] 155.

${ }^{8} 89$ BVERFGE 155 (189).
} 
In the words of Judge Gertrude Lübbe-Wolff in her dissenting opinion in the OMT case ${ }^{9}$ in 2016: "In an effort to secure the rule of law, a court may happen to exceed judicial competence".

Moreover, the ultra vires approach was never a particularly plausible concept, in particular with regard to the aspect of the functionality of a supranational legal order: If every Member State claimed the final word on EU law, we could kiss the European community of law and the idea of a common legal system good bye.

Hence, the harsh criticism of the 2009 Lisbon judgment ${ }^{10}$ didn't really come as a surprise, as this ruling ungraved and even sharpened the "ultra vires review" which had already begun to fade away.

In reaction to the criticism, the Second Senate rowed back in its Honeywell decision in 2010. ${ }^{11}$ While insisting on the hypothetical possibility to declare European action ultra vires, the Court carved out additional preconditions for this that made the actual use of the review appear to be quite unlikely. The Federal Constitutional Court pledged to involve the CJEU by way of a preliminary reference before declaring a European act ultra vires-at this point in time, the Federal Constitutional Court had never submitted any question.

Then, not every transgression of competences would qualify as ultra vires act, but only those acts that cause a structural shift in the division of powers.

And as far as ultra vires acts of the CJEU are concerned, the CJEU should even have a right to Fehlertoleranz ${ }^{12}$ some kind of margin to err.

This version of the ultra vires review could even be seen as having a stabilizing role on the overall structure, a kind of chilling effect on any European institution to respect the limits of EU powers. But this interpretation of ultra vires review ultimately rests on the condition that the sword of Damocles never gets dropped. I explored this some time ago in my Staatsrechtslehrervortrag. ${ }^{13}$

I still insist, though, that from the perspective of EU law, room for Member State's control elements can only be admissible as constitutional "identity control" (Identitätskontrolle).

Let me explain.

Invoking national constitutional identity against EU law will always be about the bilateral relationship between a single Member State's legal order and the EU legal order. The reproach of a transgression of European competences cannot be limited to this bipolar relationship, however. It affects EU law in relation to all the other Member States, as EU law cannot be ultra vires only with respect to one Member State. This is why the ultra vires argument is so dangerous for the unity of EU law.

\section{The Judgment of May 5, 2020}

With the PSPP judgment it has happened: the Federal Constitutional Court declared the act of a European institution ultra vires. Seven judges of the Federal Constitutional Court lecture the 15 judges of the Grand chamber of the European Court of Justice in rather astonishing language ("interpretation of the Treaties is not comprehensible and must thus be considered arbitrary") ${ }^{14}$ that they didn't properly scrutinize the ECB's action and therefore exceeded their

\footnotetext{
${ }^{9}$ Bundesverfassungsgericht [BVerfG] [Federal Constitutional Court] Jan. 14, 2014, 134 ENTSCHEIDUNGEN DES BundESVERFASSUNGSGERICHTS [BVERFGE] 366, para. 106.

${ }^{10}$ Bundesverfassungsgericht [BVerfG] [Federal Constitutional Court] June 30, 2009, 123 ENTSCHEIDUNGEN DES BundESVERFASSUNGSGERICHTS [BVERFGE] 267.

${ }^{11}$ [Bundesverfassungsgericht [BVerfG] [Federal Constitutional Court], Case No. 2 BvR 2661/06 (July 6, 2010).

${ }^{12}$ Bundesverfassungsgericht [BVerfG] [Federal Constitutional Court] July 6, 2010, 126 ENTSCHEIDUNGEN DES BundESVERFASSUNGSGERICHTS [BVERFGE] 286, para. 66.

${ }^{13}$ Franz C. Mayer, Verfassung im Nationalstaat: Von der Gesamtordnung zur europäischen Teilordnung?, 75 VeröFfentlichungen der Vereinigung Der Deutschen StaAtsRechtslehrer [VVdStRL], 7 (2016).

${ }^{14}$ Judgement of May 05, 2020 at Headnote 2.
} 
competences. This clears they way for the Federal Constitutional Court to scrutinize the ECB's action.

This is the point where a reader unfamiliar with the train of thought of the Second Senate may have difficulties to follow and to believe what the court did. But it is true, the Federal Constitutional Court did set out to restrain the independent (!) European (!!) Central Bank.

The legal argument used is the principle of proportionality laid down in Art. 5(1) sentence 2 and Art. 5(4) TEU which is actually a principle that indicates how to exercise an existing competence.

In the word of the Court: in view of the "considerable economic policy effects resulting from the PSPP $(\ldots)$, it would have been incumbent upon the ECB to weigh these effects and balance them, based on proportionality considerations, against the expected positive contributions to achieving the monetary policy objective the ECB itself has set."

And further:

"It is not ascertainable that any such balancing was conducted, neither when the programme was first launched nor at a any point during its implementation; it is therefore not possible to review whether it was still proportionate to tolerate the economic and social policy effects of the PSPP, problematic as they may be in respect of the order of competences, or, possibly, at what point they have become disproportionate. Neither the ECB's press releases nor other public statements by ECB officials hint at any such balancing having taken place. For this lack of balancing and lack of stating the reasons informing such balancing, the ECB decisions at issue violate Art. 5(1) second sentence and Art. 5(4) TEU and, in consequence, exceed the monetary policy mandate of the ECB deriving from Art. 127(1) first sentence TFEU."15

This is how the Federal Constitutional Court solves the core question that also let economists and lawyers clash in the oral hearing: "Is the PSPP still monetary policy (permitted) or is it already economic policy (prohibited)?” According to the Constitutional Court, if the ECB exercises what the German court considers a proper proportionality test processing all the potential economic policy effects of the program the right way, then it still counts as monetary policy.

The Federal Constitutional Court's test result is that the ECB unfortunately did not sufficiently document that it took into consideration the effects of its program, balancing the pros and cons, in order to assess its proportionality. Thus, the program has no basis in EU law, and neither has the CJEU judgment that upholds the ECB program. Hence, being outside the realm of EU law and the powers transferred to the European level by the Federal Republic when ratifying the treaties, neither the CJEU's judgment nor the PSPP are binding for Germany.

The question of hidden-prohibited-monetary financing by means of the PSPP is also discussed in the judgment. ${ }^{16}$ However, here the Federal Constitutional Court accepts the CJEU's result—no monetary financing-despite "considerable concerns".

\section{The Immediate Effects}

The Federal Constitutional Court cannot give instructions to the ECB.

Therefore, the dispositive part of the judgment (the Tenor), which is the actual decision, is limited to declaring that the Federal Government and the German Bundestag omitted to take, not further specified, "suitable measures". Further, the Bundestag and the Federal Government-notwithstanding the independence of the Central Bank - are obliged to work towards a proportionality assessment by the ECB. They must "clearly communicate their legal view" (presumably meaning the Second Senate's legal view) "to the European Central Bank."

\footnotetext{
${ }^{15}$ Judgement of May 05, 2020 at paras. 176-177.

${ }^{16}$ Judgement of May 05, 2020 at paras. 180-183, 205-206.
} 
Such letters should be quick to write.

As the most immediate consequence of the presumed ultra vires act, the German Central Bank, the Bundesbank, which the Federal Constitutional Court seems to consider within the scope of its jurisdiction, "may not participate" in the implementation and execution of the public purchase program. However, this interdiction will only become effective three months after the verdict. Until then, the proportionality considerations could be submitted and the proportionality test repaired, so to speak.

Thus, the immediate consequences of the judgment appear to be limited, although one shouldn't ignore that part of the judgment underlines that a final assessment of the ECB action can only me made with all proportionality aspects on the table.

The judgment goes well beyond the current dispute over the ECB's 2015 bonds purchase program.

\section{E. Ten Observations and Estimations}

\section{The Judgment Does Not Come as a Surprise.}

For years, vested interests have been fostering the idea that the Second Senate shouldn't be all bark and no bite. ${ }^{17}$ Those who witnessed the oral hearing, in which the bad mood of the bench was tangible, could see it coming: in a mixture of anger about the economic issues and categories slipping away from a legal grip, a grim mood about the supposedly dismissive tone of the CJEU's preliminary ruling and possibly also about the absence of the ECB in the oral hearing, which - quite rightly-had preferred not to be pulled through the arena of a constitutional court interrogation in a Member State court once again as it had happened in the OMT proceedings.

\section{The Judgment Does Come as a Surprise.}

That the Second Senate would dare to invade the ECB's highly sensitive field of action was not really certain, though. Most commentators had previously relied on the judges' common sense and prudence to not underestimate the dangers to the Euro coming with an attack on the ECB. The Egenberger case (church labour law), ${ }^{18}$ also pending before the Second Senate, seemed much more suitable for an activation of ultra vires review against the CJEU, with less far-reaching effects and nevertheless a certain symbolic content.

It appears equally surprising and worrying that the ECB case was chosen for the very first ultra vires verdict. There is almost no other plausible explanation than the intention to have an increased-especially international—visibility and the far greater practical implications.

\section{The Judgment is a Huge Disappointment}

"The judgment" is also a code for those behind the judgment. The present judgment was delivered 7 to 1 . Unfortunately, this "1" did not write a dissenting opinion, so that we do not know who the one person was who-presumably-would have judged more Europe-friendly. This is very regrettable, because ever since the Solange I case in $1974,{ }^{19}$ the dissenting opinions on European matters have been helpful as evidence to expose the contradictions in the majority opinion. And to indicate that there may be an alternative way, leading to an-arguably-better jurisprudence.

\footnotetext{
${ }^{17}$ Christian Hillgruber, Nicht nur Zähne zeigen—beißen!, Neue JuRISTISCHE WochenSCHRIFt [NJW], 8/2014, Editorial (2014).

${ }^{18}$ The prior ECJ case was ECJ, Case C-414/16, Vera Egenberger v Evangelisches Werk für Diakonie und Entwicklung e.V., ECLI:EU:C:2018:25 (Apr. 17, 2018), http://curia.europa.eu/juris/liste.jsf?num=C-414/16.

${ }^{19}$ Bundesverfassungsgericht [BVerfG] [Federal Constitutional Court] May 29, 1974, 37 EnTSCHEIDUNGEN DEs BUNDESVERFASSUNGSGERICHTS [BVERFGE] 271, para. 68.
} 
The judges who participated in the May 5 th decision were the president ${ }^{20}$ Andreas Voßkuhle, law professor in Freiburg, the judge rapporteur Peter Huber, law professor in Munich, the former prime minister of the Saarland Peter Müller, the former federal judges Sibylle Kessal-Wulf, Monika Hermanns and Ulrich Maidowski, and the law professors Doris König (Hamburg) and Christine Langenfeld (Göttingen). And only one person out of this group disagreed with the judgment. Quite a disappointment. The latter three judges, who happen to be the judges who joined the Senate last, had just voted against the majority in the UPC case, ${ }^{21}$ a quite problematic European law related decision for a number of reasons, and addressed their concerns in an elaborate dissenting opinion. This had been seen by some as a perspective towards a more moderate approach in European matters. ${ }^{22}$ Not much is left of this perspective, for the time being.

\section{Tbc - to Be Continued}

This judgment clearly encourages further legal action against the PSPP and also against the recently established Pandemic Emergency Purchase Program (PEPP) in the context of the Corona crisis.

One of the irritating features of the Second Senate's jurisprudence in European affairs is that an extremely shaky admissibility construct again and again gives standing to the same anti-European plaintiffs who are out to terminate the common currency-AfD founder Lucke, for instance, was one of them in this case.

There are other cases pending that have been filed explicitly invoking ultra vires control. That concerns in particular the aforementioned Egenberger case, dealing with church labour law.

Another confrontation with the CJEU is looming in this case as well. We may find out that the judgment of May 5, 2020 will not stay an exception.

\section{Corona-the Second Senate and Its Timing Problem}

The President of the Constitutional Court Voßkuhle was visibly uncomfortable with the situation when he opened the session on May 5, 2020. The session had already been postponed once by 3 weeks, the official reasons given were corona-related contact restrictions. It is the Corona crisis that makes the judgment appear behind the times.

With its PEPP program, the ECB is one of the few visible and proactive European institutions in the Corona crisis. Although judge Voßkuhle hastened to emphasize in his introductory remarks that the judgment does not make any statement on the ECB's Corona program-which is on the one hand stating the obvious, but then again irritates as a statement, as the parallels between PSPP and PEPP are obvious. And as the limitations for ECB action carved out in the judgment could also apply to PEPP, it is clear that the next constitutional complaint will be against PEPP. At least, Art. 122 TFEU will play a role then, which addresses special circumstances, and the Federal Constitutional Court would have the opportunity to correct its PSPP ruling.

\footnotetext{
${ }^{20} \mathrm{With}$ the end of his term as a judge on June 22, 2020, Andreas Voßkuhle left the Court. The new President is Stephan Harbarth (First Senate), Judge König is the new Vice-President, and Astrid Wallrabenstein, a law professor from Goethe University Frankfurt, was appointed to the seat of Andreas Vosskuhle as a new judge.

${ }^{21}$ Bundesverfassungsgericht [BVerfG] [Federal Constitutional Court], Case No. 2 BvR 739/17, para. 169 (Feb. 13, 2020), http://www.bverfg.de/e/rs20200213_2bvr073917.html.

${ }^{22}$ See also Bundesverfassungsgericht [BVerfG] [Federal Constitutional Court] Feb. 12, 2016, 141 ENTSCHEIDUNGEN DES Bundesverfassungsgerichts [BVERFGE] 1, para. 104 (Judge König, dissenting).
} 


\section{The FCC Fails to Fulfill Its Primary Task: Providing Stability}

Already before the Corona crisis emerged, one could increasingly have a general sense of the world order falling apart, with the bold idea of legal constraints beyond the nation state being more and more pushed back.

Corresponding forces at work in this respect on both sides of the Atlantic still encounter the persistent resistance of a community of law ${ }^{23}$ that comes with European integration.

In a world in disarray, the idea of law provides orientation and support and ensures stability. In Germany, it is the Constitutional Court's fundamental rights case law that stands for this, this is where its primary task lies. This is particularly true in times of crises such as the Corona crisis.

The Federal Constitutional Court's attack on the CJEU and the ECB runs counter to this, it destabilizes.

\section{The Judgment Is Incoherent and Contradicts the Court's Own Case Law}

Numerous aspects of the judgment are simply irritating. Here's a selection:

The building of the Federal Constitutional Court in Karlsruhe has a very transparent design with lots of windows, the judges live in a glass house, so to speak. It is from this glass house that the Federal Constitutional Court requests a proportionality test in particular from the CJEU in an utterly disproportionate manner.

Then, there is talk of arbitrariness and of a decision that is not comprehensible. It is true that this harsh wording can be explained, to some respect, by its roots in specific German constitutional law constructs. Nevertheless: we have had Willkürgerichte, arbitrary courts, in German history. The CJEU is far from this. And of course the CJEU's line of argument is coherent and comprehensible and something the average reader will be able to follow, as anyone can read. The Federal Constitutional Court simply doesn't like the argument.

There is also the accusation that the CJEU judgment is "methodologically no longer tenable". Quite a statement for seven German judges, addressing the 15 judges of the Grand Chamber of the CJEU.

Strange enough, there was not one line in the doctrinal writings on that CJEU decision in question that had accused the CJEU ruling of being methodologically untenable. The Federal Constitutional Court establishes a huge smokescreen of quotes and sources, but there is not a single reference to doctrinal writings that detect the alleged methodological failure of the CJEU-which is in itself methodological not tenable.

Furthermore, the shaky admissibility construct (based on Art. 38 of the German constitution) for the constitutional complaints directed against the ECB is ultimately about a call for respecting the democracy principle. But this is turned against a central bank, with both the constitutional court and the central bank being equally democratically precarious counter-majoritarian institutions. ${ }^{24}$

It is functional legitimacy that these institutions may invoke, at best-and now, speaking from the glass house of the Constitutional Court in Karlsruhe, these judges lecture the central bank how to conceptualize a central bank in a democratic manner. There is some irony in one countermajoritarian institution explaining democracy to another counter-majoritarian institution. It may well be that democracy is the wrong perspective to begin with when it comes to the concept of an independent central bank.

This is particularly obvious where the judgment requests that the Bundestag should "take steps" 25 with regards to the ECB — this is exactly what was supposed to be impossible. MPs calling

\footnotetext{
${ }^{23}$ Franz C. Mayer, Die Europäische Union als Rechtsgemeinschaft-Europäische Integration und 70 Jahre NJW, NEUE JuRISTISCHE WOCHENSCHRIFT [NJW], 50/2017, 3631 (2017).

${ }^{24} \mathrm{See}$, in that context, AleXander Bickel, The Least Dangerous Branch: The Supreme Court at the Bar of Politics (1962).

${ }^{25}$ Judgement of May 05, 2020 at Headnote 9, paras. 97, 107, 116, 229-232.
} 
the central bank and exerting political pressure would be a quite distinct model of central bank. And remember, the independence of the ECB was a German concern.

Besides, the CJEU is the court that has already proven in the Rimševičs case in $2019^{26}$ that it is determined to defend central bank independence.

The argument regarding the principle of democracy has its origins in the older decisions concerning EFSF and ESM by the way. In these cases the Federal Constitutional Court was able to turn to the Bundestag and to insist that the Bundestag green light any measure of these European institutions first.

With the principle of democracy as an argument, conveniently the admissibility of the action could always be secured via Art. 38 of the German constitution, even though this admissibilityconstruct is, to be very honest, methodologically doubtful.

In relation to the ECB though, there is nothing that enhancing Bundestag action could possibly achieve, since the ECB is independent.

Nevertheless, democracy sound-bites are being carried along, and in the end it is the Bundestag that is - out of the old habit-instructed to do something, somehow. One cannot help but thinking of the old Tom \& Jerry cartoons, where the protagonist is racing over the edge of the cliff and continues running through the air for quite a while, and only realizes that there is nothing to run upon when looking down below. Maybe the Senate majority should occasionally take a look down below.

There are various aspects of the arguments put forward that simply do not fit.

Even according to the Federal Constitutional Court's own categories- "carpentered in decades of fretwork in Karlsruhe deliberation rooms," as Bernhard Wegener put it ${ }^{27}$ - established in the Honeywell-decision, ${ }^{28}$ there needs to be European action that constitutes a structural shift of competences, away from the Member State. This is supposed to be the case here, although the issue at stake-proportionality - is a matter of correctly exercising competences in a specific case, which seems to be at odds with the structural argument. And if it's a structural matter how can the court assume that the acts in question can be repaired within just three months? And what exactly do the Member Sates lose structurally, in this scenario?

\section{The Decision Is Painfully German-and Hurts German Interests and EU Policy.}

There is hardly a way around this: but the hubris of lawyers, on display in various parts of the decision, the boldness to simply ignore the limits of one's own expertise, a mindset quite familiar to most German lawyers - in the present context this concerns economic implications-as well as the lecturing attitude ('let's teach the CJEU how this whole proportionality-thing works') up to the brutality of the language (,arbitrary“) ${ }^{29}$ all this will be perceived as being very German by the other European countries.

This will do major harm to German interests in the European Union, since Germany is under hegemony suspicion anyway, considering the history of the 20th century. In a nutshell:

One did not fight the German occupiers, won the war against them, allowed the Germans to rebuild their country under the condition to commit to European cooperation and peacefulness, to now let the Germans dictate your way of life, how to handle your government expenses, etc.

The overly German perspective also is part of the central methodical-technical issue throughout the Federal Constitutional Court's entire reasoning: It's the ECB's insufficient proportionality

\footnotetext{
${ }^{26} \mathrm{ECJ}$, Case 202/18, Ilmārs Rimšěvičs and European Central Bank v Republic of Latvia (Feb. 26, 2019), http://curia.europa. eu/juris/liste.jsf?num $=$ C-202/18.

${ }^{27}$ Bernhard Wegener, Verschroben verhoben!, VeRFASSUNGSBLOG (May 5, 2020), https://verfassungsblog.de/verschrobenverhoben/. There is a particluar connotation implying a subtext of engaged amateurism of the fretwork("Laubsägearbeiten") metaphor that is probably lost in the English translation.

$28 * * 126$ BVERFGE 286 at Headnote 1a.

${ }^{29}$ Judgement of May 05, 2020 at Headnote 2, paras. 112, 118.
} 
test that is at the core of the argument-note, though, that delimitation of competences is not the context where proportionality is typically discussed in domestic cases in Germany. Under the German constitution, proportionality normally comes up in the context of fundamental rights violations. And there is a debate in Germany on whether the German way of testing proportionality is really that rational and beyond subjective choices. ${ }^{30}$

As the ECB's proportionality test is considered to be insufficient, the German judges present their view of how proportionality should have been dealt with. It is quite telling that the balancing the court suggests seems to be limited to aspects in sight of Karlsruhe's worm's-eye view.

Elsewhere, there may be different or additional concerns than interest in rates on bank savings or the real estate market, elements the judges refer to.

More generally speaking, it appears quite absurd to imply that the ECB does not reflect on possible consequences of its measures. But when this is done, the ECB is adopting a European perspective, taking into consideration all kind of aspects and concerns in various countries, with a view to a European common good.

\section{In Poland, Celebrations Begin}

One of the decision's worst aspects is that it appears to give a blueprint to all those governments and, more generally speaking, political forces who are seeking to escape obligations under European law. It is true, though, that the judges also say that the general rule is that the CJEU's interpretation of EU law matters.

But what will be quoted in Poland, Hungary and elsewhere ${ }^{31}$ are the elements of the Federal Constitutional Court's jurisprudence about the final word of the national constitution, especially the final word over CJEU's decisions. You do not necessarily have to follow CJEU's decisions, that is the message.

It is also true that these blueprints are not brand-new, parts of the Federal Constitutional Court decision were already selectively quoted by the Polish government and others in the past to justify infringement of European law.

But this is exactly why the Second Senate could see this coming and had to anticipate how the decision would be instrumentalized. What happened from the perspective of the democratic forces struggling to uphold the rule of law in these countries, which includes fellow judges, is that the Federal Constitutional Court let them down.

\section{The Decision Primarily Targets the CJEU}

The consequences for the PSPP appear to be manageable; the ECB could shrug them off and return to business. The ECB is out of reach for the Federal Constitutional Court.

But the decision is highly dangerous for the CJEU, who appears to be the primary target of the decision. There is not much left of the Kooperationsverhältnis, the relationship of co-operation between Federal Constitutional Court and CJEU that was one of the central ideas of the Maastricht-decision.

What the German judges do amounts to an open declaration of war towards the CJEU. And it comes with an invitation to the other Member States' courts to join in. This has actually always been a rather annoying component of the ultra vires story told by the Federal Constitutional Court: The FCC has repeatedly suggested that their ultra vires approach also exists in most other Member States. Which is basically not correct. There are numerous constitutional reservations in

\footnotetext{
${ }^{30}$ Thorsten Kingreen \& Ralf Poscher, Grundrechte. StaAtsrecht II para. 344 (35th ed. 2019).

${ }^{31}$ See for example the Polish Prime Minister Morawiecki describing the FCC's judgement as one of the most important in the history of the EU, in EU droht Deutschland mit Verfahren, Frankfurter Allgemeine Zeitung [FAZ], (May 09, 2020), https://www.faz.net/aktuell/politik/eu-droht-deutschland-mit-vertragsverletzungsverfahren-16762097.html.
} 
other Member States. There have been two cases that may qualify as ultra vires cases. ${ }^{32}$ But no court has put himself in the place of the ECJ the way the Federal Constitutional Court does it in the PSPP case.

All this may not only lead to a more difficult relationship between the CJEU and Member State courts, it may also affect the horizontal relationship between the highest courts in the Member States.

It is hard to explain where exactly this anger and aggression against the CJEU, noticeable between the lines of the judgment and quite obvious during the hearings, come from. It is true that the CJEU's response to the PSPP preliminary reference was rather thin in some points, but that is basically the CJEU style. Actually, the judges do know each other quite well. Andreas Voßkuhle, the Federal Constitutional Court's president, is even a member of the committee established under Art. 255 TFEU which examines the applications for CJEU- judges.

What really goes on in terms of institutional and personal interaction during the regular encounters of the courts I do not know. Arguably all this is a very simple story: After the historical first ever preliminary reference submitted by the Germans in the OMT case, ${ }^{33}$ the CJEU ruling ${ }^{34}$ was a big disappointment as the European judges didn't agree with the view of the Federal Constitutional Court. As a consequence more or less the same questions were submitted with the PSPP-reference, ${ }^{35}$ but the CJEU remained unimpressed and gave its own answer, again. And that had to be punished. If this is what happened, ${ }^{36}$ it is the human factor that mattered most. For some it may sound a lot like Kindergarten. The decision of May 5, 2020 may ultimately also be a consequence of judicial egos, not only on one side, clashing.

La guerre des juges aura lieu: The CJEU will have to respond to this hostile act. This requires an appropriate proceeding. A sober analysis from an EU-law standpoint yields that with the decision of May 5, 2020, the Federal Constitutional Court violates Art. 267(3) TFEU and Art. 19 TEU, although this is slightly concealed in the dispositive part of the decision.

The Federal Constitutional Court calling on the Federal Government and German Parliament to take action to somehow influence the ECB could be read as a violation of the treaty provisions that guarantee the ECB's independence. Accordingly, the European Commission will have to consider initiating infringement proceedings. ${ }^{37}$

This may well lead to the CJEU declaring that Germany violated its treaty obligations. The fact that courts are independent in the Member States will not be accepted as an excuse. The Commission used to abstain from bringing infringement proceedings to the CJEU when courts were involved, instead they would typically only issue letters of formal notice. This has changed. Nowadays, even large Member States are being sued if their courts violate EU-law. A recent example is the sentencing of France in $2018^{38}$ because of a Conseil d'Etat decision in the Accor-case. ${ }^{39}$

\footnotetext{
${ }^{32} \mathrm{Pl}$. ÚS 5/12, Slovak Pensions, Czech Constitutional Court case of 31 January 2012 [hereinafter Slovak Pensions]; Court of Justice: Judgment of 19 April 2016, Case No. C-441/14, Dansk Industri (on behalf of Ajos A/S) v. Estate of Karsten Eigil Rasmussen [GC] (Den).

${ }^{33} 134$ BVERFGE 366.

${ }^{34}$ ECJ, Case C-62/14, Gauweiler et al. v. Deutscher Bundestag, ECLI:EU:C:2015:400 (June 16, 2015), http://curia.europa.eu/ juris/liste.jsf?num $=\mathrm{C}-62 / 14$.

${ }^{35}$ Bundesverfassungsgericht [BVerfG] [Federal Constitutional Court] July 18, 2017, 146 ENTSCHEIDUNGEN DES BuNDESVERFASSUNGSGERICHTS [BVERFGE] 216.

${ }^{36}$ The Judge rapporteur of the case, Peter M. Huber, basically confirms this in his contribution at Grüne Europagruppe's Webinar "After the ECB judgement-Is the EU community law in jeopardy?", YoutUBE (June 18, 2020), https://www. youtube.com/watch?v=dxtMK3XaZlM.

${ }^{37}$ Ursula von der Leyen, President, Eur. Comm'n, Statement (May 10, 2020), https://ec.europa.eu/commission/presscorner/ detail/en/statement_20_846.

${ }^{38}$ ECJ, Case C-416/17 Eur. Comm'n v. French Republic, ECLI:EU:C:2018:811 (Oct. 4, 2018), https://eur-lex.europa.eu/legalcontent/EN/TXT/HTML/?uri=CELEX:62017CJ0416\&qid=1592487945274\&from =EN.

${ }^{39}$ Conseil d'Etat [CE] [Council of State], Dec. 10, 2012, No. 31.7074; Conseil d'Etat [CE], Dec. 10, 2012, No. 31.7075.
} 
In case of the treaty infringement continuing, e.g. through confirmation of the decision's rulings in subsequent decisions, even a penalty payment can be inflicted. Resolving the infringement could be achieved for example by modification of the Federal Constitutional Court Act (BVerfGG) or by constitutional amendment, amending Art. 88, with the aim to explicitly take away Federal Constitutional Court jurisdiction to rule over ECB matters. A more general approach would be to restate the obvious in German law: that the Federal Constitutional Court is obliged to respect CJEU rulings. In any event, there would still be the possibility for the Federal Constitutional Court to invoke the eternity clause of Art. 79(3) of the German constitution. Nevertheless, nobody could deny that considerable efforts towards overcoming the infringement were undertaken.

The whole matter could actually also be taken to the CJEU by means of a state liability claim introduced at a German civil court against the Federal republic. ${ }^{40}$ The plaintiff would have to argue that he or she suffered a loss by reason of the non-respect of the CJEU ruling by the Federal Constitutional Court, asking for compensation.

A standard infringement procedure would be the sober, civilized and therefore correct way to deal with conflict in the community of law. The Federal Constitutional Court broke the rules, so we need to sort this out, following the procedure foreseen by the treaties. It is also clear, though, that there is no alternative to the courts cooperating. This is the lesson taught by the history of federalism and similar conflicts between courts in the past, just take the example of courts in the USA in the 19th century before and after the Civil war. ${ }^{41}$

What is at stake is nothing less than the European community of law. ${ }^{42}$ Without the underlying fabric of a nation state that supplies additional coherence, this construct still remains extremely fragile. Its central components are on the one hand the CJEU, still a unique transnational court, and on the other hand the mutual trust of all courts in the EU in the fact that EU related verdicts are being obeyed by all courts in the European Union.

If this collapses, there will be a risk of the entire system winding down towards some kind of judicial rule of the jungle: The rule of the strongest court. This would be determined along the parameters of size, power and force, political influence and economical impact of the respective Member State.

With such a development, the key idea of European integration, peace in Europe through law and legal equality would be dismantled.

\section{F. Concluding Thoughts}

"Germany's constitutional judges seem to live in a far, far away galaxy from the financial reality" 43 - far, far away: the Star Wars saga may also offer material to capture the epic struggle between powerful national and European institutions. But let me stick with Star Trek.

Star Trek, the "Wagon Train to the stars", 4 is basically the Far West brought to the 23rd century: Adventures and challenges of the frontier pioneers exploring unknown and uncharted territory. The latter is also an accurate description of the monetary union, arguably of the entire

\footnotetext{
${ }^{40}$ Case C-6/90, C-9/90, Francovich and Others v. Italian Republic, ECLI:EU:C:1991:428 (Nov. 19, 1991), http://curia.europa. eu/juris/showPdf.jsf?text $=\&$ docid $=97140 \&$ pageIndex $=0 \&$ doclang $=$ EN\&mode $=1$ st\&dir $=$ \&occ $=$ first $\&$ part $=1 \& \mathrm{cid}=693233$.

${ }^{41}$ Franz C. Mayer, Kompetenzüberschreitung und Letztentscheidung-Das Maastricht-Urteil des Bundesverfassungsgerichts und die Letztentscheidung über Ultra vires-Akte in Mehrebenensystemen-Eine rechtsvergleichende Betrachtung von Konflikten zwischen Gerichten am Beispiel der EU und der USA, MÜNCHENER UNIVERSITÄTSSCHRIFTEN 290 (2000).

${ }^{42}$ Mayer, supra note 23. See also T. Ackermann, Editorial: Das europäische Wettbewerbsrecht als Kollateralschaden des PSPP-Urteils des Bundesverfassungsgerichts?, NEUE ZEITSCHRIFT FÜR KARTELLRECHT 281 (2020), who points to the risk that the proportionality test suggested by the Federal Constitutional Court may be used in the realm of competition law or state aid control.

${ }^{43}$ Charles Secondat et al., The German Constitutional Court's decision about the European Central Bank's OMT [Outright Monetary Transactions] mechanism: A masterpiece of judicial arrogance, 30 EUR. POL. BRIEFs 5 (2014).

${ }^{44}$ Gene Roddenberry's Star Trek. The Original Cast Adventures 3 (Douglas Brode \& Shea T. Brode eds., 2015).
} 
European integration project: uncharted territory and a potentially hostile environment with a post-1945, 20th century world order increasingly falling apart. Having the courts and the central banks in the EU working together instead of working against each other will be crucial to master the challenges of this voyage into uncharted legal, political and economic territory in the 21 st century. 